\title{
Topical Powder Dosage Form
}

National Cancer Institute

\section{Source}

National Cancer Institute. Topical Powder Dosage Form. NCI Thesaurus. Code C91193.

A powder intended for administration to a body surface. 